\title{
Opportunity and Response: Social Factors in Agricultural Development in Maharashtra
}

\section{Baburao S. Baviskar}

Agriculture in Maharashtra, as in some other States of India, is largely dependent on the vagaries of nature. Inadequate and uncertain rains are a common, if not regular, feature in several of its districts. This often leads to scarcity conditions. The irrigation development in the State is much below the national average. Only 6.8 per cent of the State's cropped area was under irrigation as against 20 per cent in the country in $1963 / 641$. A primary aim of Governments has been to increase this percentage. Their second, and equally important, means of promoting agricultural development has been to provide credit, fertilizers, and marketing and processing facilities largely through the establishment of a network of cooperatives. However, the creation of facilities in itself does not produce the desired results. Some people respond to the facilities positively, others do not.

Different social groups respond differently. Why should this be so? Often, differential responses are a result of the differing material conditions of the groups and their perceptions of their own interests. It is also, sometimes, a matter of values and attitudes. Of course interests and attitudes are interrelated and they often influence one another. ${ }^{2}$

This paper is about an example of such interrelation. It is a case study of agricultural development in Ahmednagar district of Maharashtra and discusses the responses of different caste groups to the development process. I shall mainly concentrate on new opportunities created by the provision of irrigation facilities and the expansion of cooperative activities.

In any discussion of rural society in India, the importance of caste cannot be over-emphasized. This does not mean that class analysis is unimportant or that class consciousness does not exist. I shall, however, deal mainly in terms of caste because I am concerned with differences among people all of whom broadly belong to the same class and who seem to act more as members of particular castes. I am mainly concerned with sugarcane growers who are economically better

\footnotetext{
1 Maharashtra 1969, Government of Maharashtra, Bombay 1969, p.91.

2 For a discussion on this, see André Béteille, "Ideas and Interests: Some Conceptual Problems in the Study of Social Stratification in Rural India", International Social Science fournal, Vol. XXI No. 2, 1969, pp. 219-34.
}

off than ordinary 'dry' farmers and agricultural labourers.

\section{Irrigation: the differential response}

Although Ahmednagar district has a rich soil, it often faced famine conditions due to uncertainty of rains. Traditionally it was an area of subsistence farming and 94 per cent of its land was used for grain crops such as bajra, jowar, pulses and oilseeds. Cash crops such as sugarcane or cotton were almost non-existent. A large number of peasants were heavily indebted to moneylenders a majority of whom were Marwari and Gujarati traders. The exploitation of the peasants by the moneylenders resulted in peasant riots against the moneylenders in the early $1870 \mathrm{~s}$. The riots were concentrated in parts of Ahmednagar and some of the neighbouring districts. This led to the appointment of the Deccan Riots Commission of 1875. Following the recommendations of the Commission, the Deccan Agriculturists' Relief Act of 1879 was passed to alleviate the condition of the agriculturists affected by the moneylenders' activities.

The latter part of the nineteenth century witnessed frequent famines in the area due to failure of rains. There was a serious famine in 1877 followed by drought conditions in subsequent years. A large number of local people had to migrate to the neighbouring district of Khandesh in search of food and employment. They made up over 18 per cent of the district's population during 1891$1901 .^{3}$ This led to the appointment of the Famine Commission of 1901 and the Irrigation Commission of 1903. Both the Commissions recommended the creation of irrigation facilities to improve the economic lot of the agriculturists. The Deccan Riots Commission and the Famine Commission had also recommended provision of easy and cheap credit to the peasants.

The first major step in the development of the area was the construction of irrigation canals on the Godavari and Pravara rivers in 1911 and 1920 respectively. The canals supplied water to irrigate nearly 100,000 acres of land in Kopargaon, Shrirampur and Rahuri talukas of the district. Initially the canal water was supplied at a very 3 Government of India, Imperial Gazetteer of India, Vol. 5, $397 \mathrm{ff}$. 
cheap rate, but the farmers were found to be reluctant to utilize it. ${ }^{4}$ The big investment in the construction of the dams, reservoirs and canals thus appeared to be wasted.

Who were the local peasants and why were they apathetic to the new opportunity which was created especially for their benefit? As in other parts of Maharashtra, the Marathas enjoy the dominant position among the cultivating caste groups in the area. They are numerically preponderant and own and cultivate the bulk of the land. Traditionally they also enjoy political power as the office of village headman was often occupied by a Maratha on a hereditary basis. There were other cultivating castes locally known as Karekars, Vanjaris and Dhangars who were numerically small, enjoyed slightly lower ritual status and did not have access to the office of village headman. The Marathas and the others did not come forward to utilize the canal waters for a number of reasons. First, they had no experience and skill in irrigation farming. Second, they did not have the necessary capital resources to raise irrigated crops which required greater expenditure. They had been impoverished due to successive failure of crops and many of them were still overburdened by debts. Third, there was a widespread belief that regular use of canal water reduced the fertility of the soil. Fourth, initially the lack of proper drainage systems in the canal area led to waterlogging which scared the cultivators.

The availability of canal waters in the area attracted a group of farmers belonging to the Mali caste from the neighbouring Poona district. Initially about a hundred Mali families came to the area, took land on lease from the local landowners and started cultivating sugarcane. The Malis were attracted by easy availability of land and canal water at relatively cheap rates. Traditionally they were cultivators of irrigated crops. In their home district they cultivated vegetables and sold their produce in the Poona city market. Some of them engaged in small trading. They bought vegetables in the surrounding villages and sold these in the city market at a profit. Thus they were economically in a better position than the local cultivators. As they faced pressure on land in their own area, they migrated to other areas whenever they found opportunities of cultivating irrigated lands. For example, when the Nira canals were constructed in the Baramati area in 1898, some Mali families settled along those canals. Similarly some of them went to Bawda area in 1903 when canal water became available there. Later they

4 Henry Orenstein has also reported the initial reluctance of the farmers in Poona district to utilize canal waters for irrigation. See his Gaon: Conflict and Cohesion in an Indian Village, Princeton University Press, 1967, p.237. migrated to Sholapur district when similar opportunities emerged there. Thus the Malis had the necessary experience and skills to cultivate irrigated lands; they had experience of marketing; they had better financial resources to undertake cultivation of cash crops; and they were forced to look for new opportunities due to pressure on land in their own area. Moreover, they had a tradition of migrating to new areas in search of irrigated lands. They were innovators and entrepreneurs by culture in the sense that they had the necessary tradition.

The local landowners, mostly Marathas but some others as well, were content to give their lands to Malis on a low rent. The poorer among them sometimes worked as wage labourers for the Malis. The Malis were commercial farmers (as opposed to the local subsistence farmers) in a true sense. They maintained detailed accounts of their farm operations and called it a dhanda (business). Since the lands they cultivated were taken on lease (it was not ancestral property) and they had come to the area to make money, they developed 'business' attitudes towards agriculture. Unlike the local cultivators who lived in villages, the Malis preferred to live in vastis (farm houses) with their farm labourers which enabled them to supervise their farm work more regularly and closely. The canal water often reached the individual farms during the night and living on the farm made it easier to irrigate the land under close supervision. If they obtained better lands on lease at another location, they shifted their vastis to the new place. Thus they were not attached to any village locality but to their farming business. The Malis cultivated sugarcane, processed it into gur (jaggery) and sold it in the markets at the neighbouring towns. In the course of time, many of them became rich and some of them bought the lands which they had obtained on lease. The success of the earlier migrants attracted more Malis and during a period of twenty years nearly 400 Mali families came to the area. The Malis could be called the pioneers of commercial farming in the area.

\section{The first factories}

Meanwhile the local Marathas and other cultivating castes also learnt sugarcane growing although initially they could not attain the same proficiency as that of the Malis. There was an overall expansion in sugarcane cultivation. However it did not last very long. The boom following the First World War was over and the depression came with a fall in gur prices. The Government found that the canal water was not fully utilized. This led to the appointment of the Deccan Canals Financial Improvements Committee in 1932. The 
Committee recommended encouragement of sugarcane cultivation in the canal areas through the establishment of sugar factories by offering potential entrepreneurs certain facilities and concessions in securing lands on lease, fixation of rents, and the supply of canal water at a cheap rate. In response to these concessions, half a dozen sugar factories were established during the thirties. These factories were joint stock companies controlled by industrialists from Bombay. They had their own sugarcane farms on the lands leased from the local landowners. In addition, they bought cane from local growers including the Malis.

The canegrowers now had two alternatives. They could either process their cane into gur or supply it to the factories. Both the alternatives were far from satisfactory. The gur prices were subject to great fluctuations and the producers often suffered severe losses. The factory owners exploited the canegrowers in several ways. At times they refused to buy the cane; they cheated in weighing; they did not offer reasonable prices; and generally they delayed payment. There was a need to provide a stable market and remunerative prices to the canegrowers. This resulted in the establishment of cooperative sugar factories and the expansion of the cooperative sector.

\section{Development of cooperatives}

Although the Cooperative Societies Act was passed as early as in 1904, cooperatives were established in the area in significant numbers only after 1920 to provide credit to the sugarcane-growers. It was soon realized that providing credit was not enough. The canegrowers had to depend upon local Marwari and Gujarati traders for buying fertilizers and other inputs and for selling their gur. In order to help canegrowers in this respect, the Cooperative Sale and Purchase Union (CSPU) was established in 1932. The CSPU supplied fertilizers and other inputs to its members and helped in marketing their gur. While the Marathas joined cooperatives in large numbers, the Malis, Karekars and other minority castes hesitated to do so. The cooperatives were managed by elected committees and each member, irrespective of his economic position, had only one vote. Since the Marathas outnumbered other castes, the latter feared that the cooperatives would be dominated by the Marathas which would strengthen their position vis-à-vis others. The Malis found a way out by forming the Big Bagaitdar Cooperative Societies. ${ }^{5}$ Most of the Karekars, for fear of

5 Bagaitdar means cultivator of irrigated lands. The sugarcane growers are often called bagaitdars. The membership of the Big Bagaitdar Societies was restricted to those who cultivated ten or more acres of cane. As most of the Malis were big cane growers, they managed to keep a control over these societies by keeping out a large number of small Maratha bagaitdars.

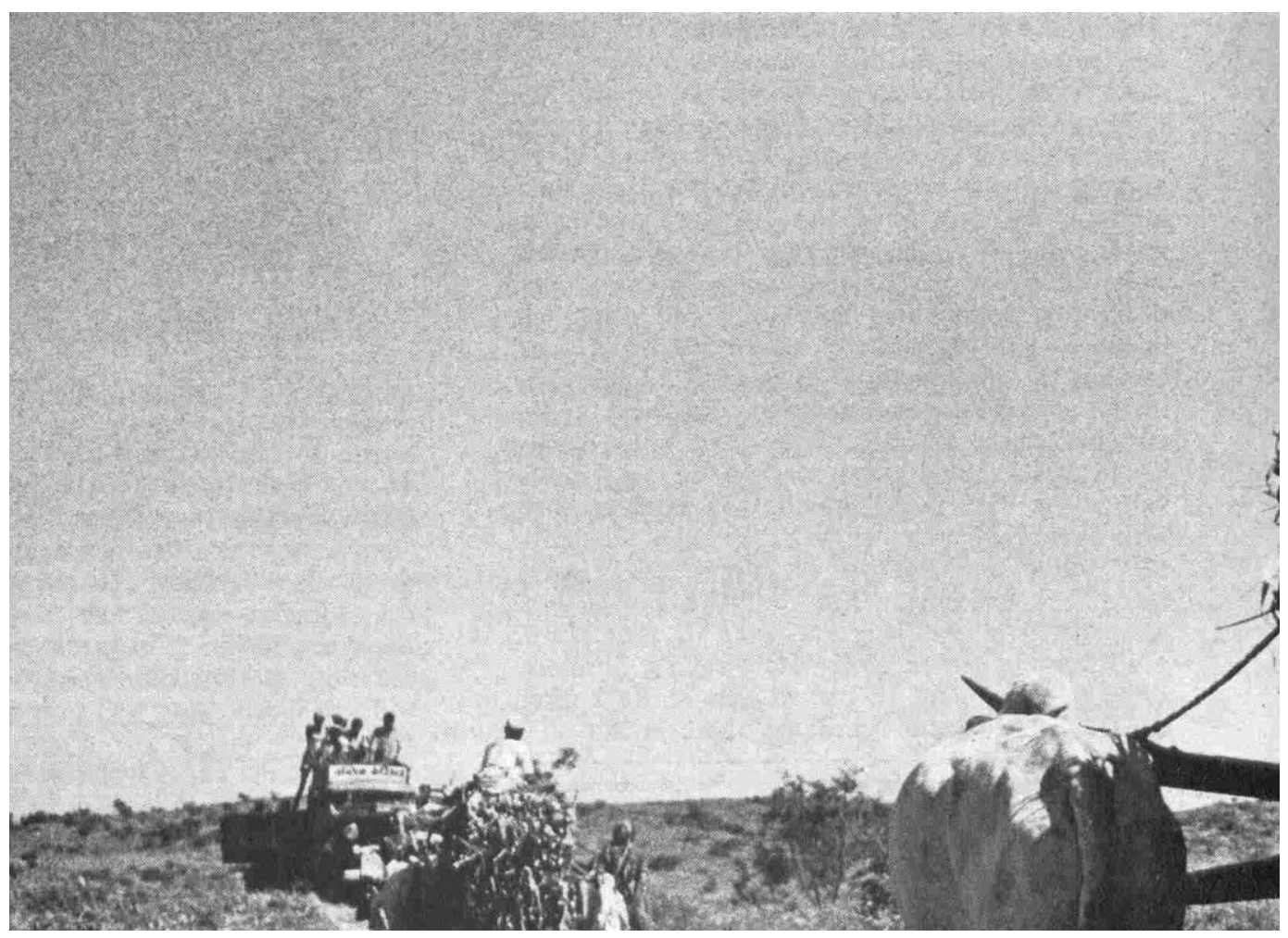


Maratha domination, kept themselves aloof from cooperatives and continued to depend on the Marwari and Gujarati traders for their needs.

While the arrival of the canal waters created cleavages between the Malis and other outsiders on the one hand, and the Marathas and other local caste groups on the other, the cooperatives led to the cleavages between the Marathas on the one hand and the minority castes on the other. The Marathas resented the fact that the Malis, who were outsiders, came to their area and became rich by exploiting their lands and canal water. Some Maratha leaders launched a campaign against the Malis, persuading people not to give their lands to them on lease and pressurizing the Government to give a preference to local farmers in the distribution of canal waters. It was generally felt that the canals and the sugar factories had not really helped the local people. The Malis, as the pioneers, had reaped the greatest benefit. Later the sugar factories, again owned by outsiders, had made profits at the cost of sugarcane-growers. In 1948, Ganpatrao Autade, a rich Maratha canegrower, with the help of some eminent coperators and encouragement from the Government, initiated a move to establish a cooperative sugar factory to provide a stable and remunerative return on sugarcane and to escape exploitation by the private factory owners. While the Marathas welcomed the proposal, he encountered opposition from others. The private factory owners opposed it because it would adversely affect the supply of cane to their own factories. They would no longer be able to buy cane on their own terms as they had been doing so far. The Gujarati and Marwari traders opposed it because it would threaten their trade in gur. The minority castes such as the Malis and Karekars were against it for fear of Maratha domination in the new factory. As 'business-orientated' sugarcane growers, the Malis realized the economic advantages of having a sugar factory. Some of their kinsmen had successfully established a factory of their own in Sholapur district and they had personal knowledge of the benefits from the factory. Their opposition emerged from a sense of insecurity being outsiders and a minority. They feared that the new factories would strengthen the position of the Marathas who might use their new power to threaten the economic position of the Malis.

The new proposal required both share capital and an adequate acreage of cane with the shareholders. The Malis had both. They were bigger cane growers and also possessed resources to buy shares. But the indifference and, to some extent, hostility on the part of the Malis and other minority castes frustrated Autade. $\mathrm{He}$ had to give

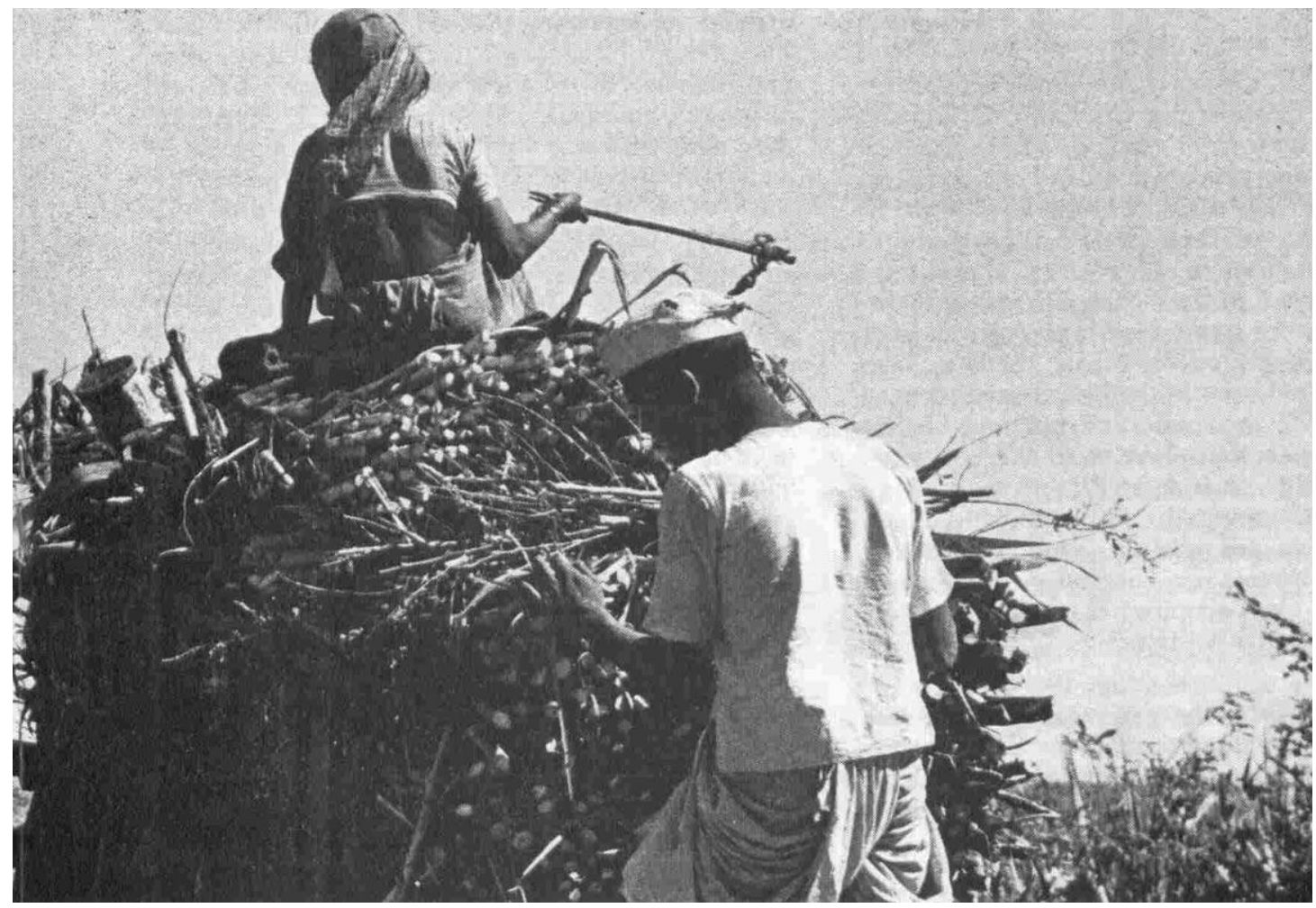


up the idea of starting a sugar cooperative and return whatever money he had collected from the people.

Autade made another attempt in 1951, and this time he succeeded. In order to allay the suspicions of the trading and other minority castes, he persuaded a local Marwari trader to become one of the promoters of the factory. Two Mali leaders were made members of the first nominated board of directors which worked for three years from 1953 to 1956. After 1956, when the elected directors took over, for about four years, three seats on the board were reserved for those shareholders who held shares worth more than ten thousand rupees and supplied more than 10 acres of cane. This, to some extent, ensured the election of big shareholders who belonged to the minority castes. Two announcements by the government also helped the promoters: first, the policy of favouring the licensing of sugar factories in the cooperative sector and, second, the policy of disallowing the sugarcane growers in the canalirrigated areas to cultivate more than six acres of cane. However, those who joined a cooperative sugar factory were to be exempted from this rule and allowed to cultivate up to 25 acres of cane. As most of the Malis were big cane growers, they saw the threat to their cane growing operations and joined the factory as shareholders without delay. Thus Autade and his fellow promoters succeeded in collecting enough share capital and the factory was soon erected and went into production in 1956.

The factory helped the sugarcane growers improve their economic position by providing a regular and attractive return for their produce. It also helped them to increase their cane yield per acre through its extension services. Sugarcane growers in different parts of the district and the State started demanding more cooperative sugar factories. In a period of less than 10 years, eight more factories were established in the district and more than 30 appeared in other districts. The factories brought about a significant transformation in the social, economic and political life in the rural areas. As they developed, the cooperatives in other fields, such as credit and marketing, also developed, mutually strengthening one another. Ahmednagar district soon became a major area of sugarcane cultivation and sugar production. It also acquired a reputation for successful cooperative activities.

The cooperatives did strengthen the position of the Marathas vis-à-vis the other castes. With the advantage of their numerical strength and their links with the Government and the ruling Congress party, they acquired a decisive contro! over the cooperatives which in turn helped them to improve their economic position. The Malis and other minority castes resent the fact that the Marathas have acquired so much power through their control over cooperatives.

\section{Conclusion}

The foregoing analysis shows how the different caste groups perceived their interests and how their interests and attitudes influenced their ability to exploit the new opportunities. The events following the construction of irrigation canals bring out the significance of cultural factors such as experience and skills in irrigated farming, access to capital resources, ability to change over from subsistence to commerical farming, and willingness to migrate from one area to another in search of better opportunities. Since the Malis were in a favourable position in these respects, they were the first to benefit most from the canals. Of course, in the course of time, the local Marathas and others also acquired the necessary skills and joined in the process of commercial farming. But the role of the Malis as the initiators of this process cannot be ignored. The Malis were helped by their favourable attitudes in this process.

In the development of cooperative sugar factories and other cooperative ventures, the Marathas were enthusiastic but the Malis and other minority castes were not. Here the hesitation on the part of the minority castes resulted not from economic but political considerations. As successful commercial farmers they realized the economic benefits of starting a sugar factory, but they were apprehensive of its effect on the relative balance of power among the different caste groups. But they could not stop the expansion of cooperatives and the consequent political advantage gained by the Marathas. The cooperatives helped the Marathas to improve their economic position.

In the constellation of forces favouring the creation of cooperatives, both the big grower/small grower/merchant class division, and caste group identification had an effect, but these interests, to a great extent, coincided with caste divisions and were articulated, at least by the minority castes, in caste terms.

The process of agricultural development described above brings out the role of social and cultural factors in the response to new economic opportunities. Like all other case studies, this one also cannot lead to any universal generalizations, but it is hoped that it contributes, to some extent, to our understanding of the process of agricultural development in India and, perhaps, in some other parts of south Asia. ${ }^{6}$

6 I am grateful to Michael Lipton for his valuatle comments and suggestions on the earlier draft of this paper. 